\title{
Osteochondroma of Mandibular Ramus and Condylar Neck: Simultaneous Resection and Reconstruccion with Personalized Alloplastic Joint Prosthesis
}

\author{
Osteocondroma de la Rama Mandibular y Cuello del Cóndilo: Resección y \\ Reconstrucción Simultánea con Prótesis Articular Personalizada Aloplástica
}

\author{
Gonzalo Martinovic Guzman'; Andrea Paz Carmona Avendaño; \\ Cristobal Rueda Lama ${ }^{3}$ \& Carlos Plaza Alvarez ${ }^{4}$
}

\begin{abstract}
MARTINOVIC, G. G.; CARMONA, A. A. P.; RUEDA, L. C. \& PLAZA, A. C. Osteochondroma of mandibular ramus and conylar neck: Simultaneous resection and reconstruccion with personalized alloplastic joint prosthesis. Int. J. Odontostomat., 14(3):363-366, 2020.

ABSTRACT: Osteochondromas are benign osteogenic tumors that can attain great size, which may require resection and additional treatment to restore the jaw's shape and function. In this report, an osteochondroma located on the mandibular ramus and neck of the condyle was resected and reconstructed simultaneously through a total joint replacement. After the surgery, the patient remains asymptomatic and recovers opening and closing ranges, phonation and the masticatory function. The immediate reconstruction after resection is a good alternative to avoid a second operation and the presurgical virtual planning ensures the complete removal of the lesion using cutting guides and covering the entire defect with a customized alloplastic joint prosthesis.
\end{abstract}

KEY WORDS: osteochondroma, personalized alloplastic joint prosthesis, total joint replacement, benign osteogenic tumor.

\section{INTRODUCTION}

Osteochondroma is a benign bone tumor that appears as a sessile or exophytic pedunculated bone projection arising on the external surface with a cartilaginous cap, where the bone component is continuous with the underlying bone. When found in the jaw, this tumor is more frequent in the coronoid process and mandibular condyle, it may develop to a large size. Therefore, following resection it additional treatment such as facial or joint prosthesis may be required, to restore the jaw's shape and function (Fletcher et al., 2002; Kitsoulis et al., 2008; Ghom, 2010; Mehra et al., 2016). We present the resection and immediate reconstruction with a joint prosthesis of a huge osteochondroma in the mandibular ramus and condylar neck.

\section{CASE REPORT}

A68-year-old patient, without morbidity, was referred to the maxillofacial service at the Military Hospital for an intense hemimandibular pain on the left side that started abruptly 6 months prior to consultation; pain was continuous with the same intensity and radiated to the temporal region. Patient finally sought medical help due to difficulty speaking and eating. Clinical examination revealed limited mouth opening without changes in occlusion. A maxillofacial computerized tomography (CT) showed an exophytic lesion on the medial side of the left mandibular ramus measuring $12 \mathrm{~mm}$ on its anteroposterior axis and cephalocaudal axis, and $16 \mathrm{~mm}$ on its transverse axis located in front of the styloid apophysis, occupying the parapharyngeal space (Fig. 1). The diagnostic impression was osteochondroma.

${ }^{1}$ OMS Staff Maxillofacial Surgery and Traumatology Service, Military Hospital, Santiago. Master's Program in Medical Sciences, Universidad de la Frontera, Temuco, Chile.

2 DDS Resident Maxillofacial Surgery and Traumatology Service, Military Hospital, Santiago, Chile.

${ }^{3}$ OMS Resident Maxillofacial Surgery and Traumatology Service, Military Hospital, Santiago, Chile.

${ }^{4}$ OMS Staff Maxillofacial Surgery and Traumatology Service, Military Hospital, Santiago, Chile. 

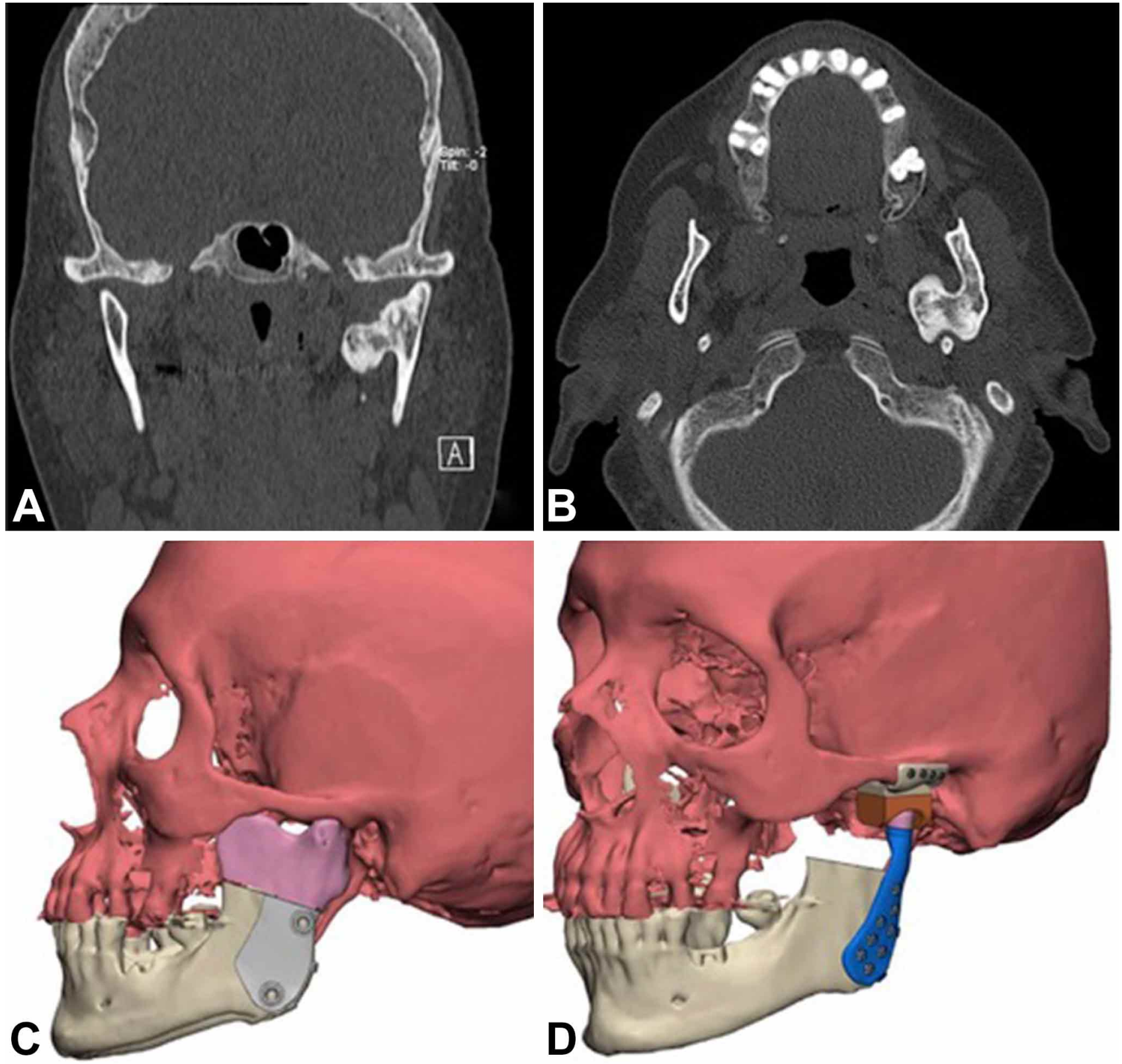

Fig. 1. Maxillofacial CT: Axial CT shows the tumor located on the medial side of the left mandibular ramus, in front of the styloid apophysis, occupying the parapharyngeal space without displacing muscular structures.

The surgical team decided a resection of the tumor and reconstruction with a customized alloplastic joint prosthesis (Artfix, Sao Paulo, Brazil). A modified guide was used at the level of the mandibular angle for tumor resection and condylectomy. Subsequently, the discectomy and removal of the tissues of the joint capsule is carried out. The mandibular ramus and condyle osteotomy was performed removing the tumor lesion with a safety margin. Two fragments of irregular bone tissue corresponding to the mandibular condyle and the resected specimen was obtained (Fig. 2). The component for the glenoid fossa is fixed to the lateral portion of the zygomatic arch and the condylar mandibular component is fixed to the remaining bone tissue, according to planning. The fat autograft obtained from the suprapubic region is placed around the joint surfaces of both components to avoid formation of heterotopic bone. Finally, all approaches were closed. 

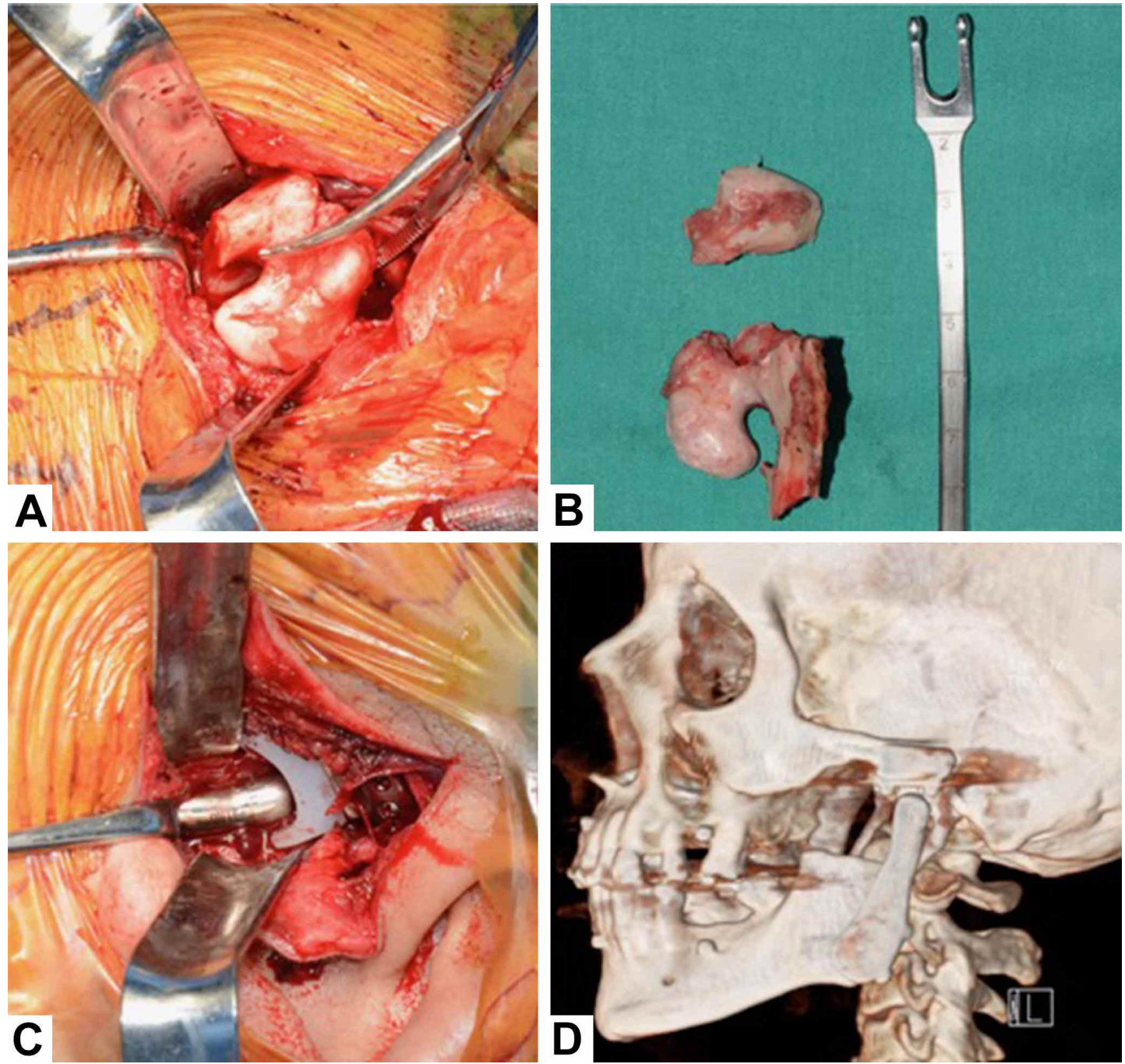

Fig. 2. Mandibular Condyle and Resected Specimen: Resecction of the tumor lesion with a safety margin, when two irregular bone tissue fragments are obtained.

The histopathological characteristics confirmed an osteochondroma, with normal histological limits, $0.7 \mathrm{~cm}$ from the surgical margin without evidence of malignancy. The control CT showed the complete resection of the left mandibular osteochondroma with condylectomy and the prosthesis system have well-positioned screws without lysis, maintaining relations between dental arches (Fig. 3). Six months after surgery, the patient remains asymptomatic and recovers opening and closing ranges, phonation and the masticatory function.

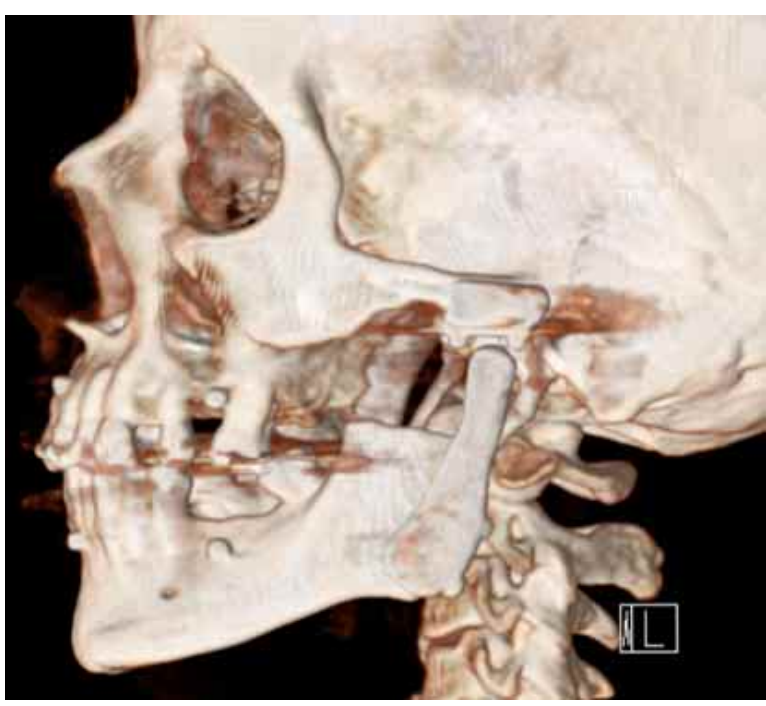

Fig. 3. Maxillofacial CT reconstruction: Sagital CT shows complete resection of the left mandibular osteochondroma with condylectomy and the glenoid fossa affixed to the lateral part of the zygomatic arch and the condylar$\mathrm{m}$ a $\mathrm{n}$ d i b u l a r component affixed to the remaining bone tissue, maintaining relations between dental arches. 


\section{DISCUSSION}

The surgical treatment of mandibular osteochondromas involves resection of the tumor and generally the condyle, which must be reconstructed because it is essential to maintain TMJ's function (Mehra et al.). The resection is usually curative and no recurrence or malignant transformation has been reported, so the recurrence may be due to incomplete removal (Kitsoulis et al.). In this case, the mandibular condyle could not be preserved, because the tumor extended to the condylar neck, thus radical resection was necessary. This implied a complete condylectomy and immediate joint reconstruction using an extraoral approach, because the anatomical location of the tumor makes access difficult, making it impossible to use other approaches such as endoscopy.

The customized joint prostheses adapts appropriately to the anatomical structures to achieve stability, functional compatibility and mechanical strength to resist chewing forces that offers long-term predictability. It also eliminates the need for a second surgical site, associated morbidity, reduces time in the operating room, minimizes the effects on connective tissue/autoimmune disease and other pathologies, that can cause the destruction of autogenous tissues used to reconstruct the TMJ. Furthermore, it is an effective way to treat distorted and mutilated joint anatomies, without depending on the vascularization of periarticular tissues. This is essential to autogenous reconstruction, improves mouth opening and the quality of life. It also reduces dietary limitations and significantly improves life functions such as chewing, speech and swallowing (Wolford et al., 2003; Mercuri, 2012; Burgess et al., 2014; Mehra et al.; Elledge et al., 2017; Rodrigues et al., 2018).

Virtual 3D planning and cutting guides play an essential role in surgical procedures involving mandibular and TMJ tumor lesions, since they allow an accurate transfer of the virtual planning to the surgical field, achieving the procedure in a single operating time and a precise condylar resection (Mehra et al.; Gerbino et al., 2017).

This case suggest that immediate reconstruction after resection is a good alternative to avoid a second surgery and the pre-surgical virtual planning ensures the complete removal of the lesión.
MARTINOVIC, G. G.; CARMONA, A. A. P.; RUEDA, L. C. \& PLAZA, A. C. Osteocondroma de la rama mandibular y cuello del condilo: Resección y reconstrucción simultánea con prótesis articular personalizada aloplastica. Int. J. Odontostomat., 14(3):363-366, 2020.

RESUMEN: Los osteocondromas son tumores osteogénicos benignos que pueden alcanzar grandes tamaños, los cuales requieren de resección quirúrgica y generalmente de algún tratamiento adicional para restaurar la forma y la función mandibular. En este caso, un osteocondroma localizado en la rama mandibular y el cuello del cóndilo fue reseccionado y reconstruido simultáneamente a través de un reemplazo articular total. Después de la cirugía, el paciente permanece asintomático y recupera los intervalos de apertura y cierre, la fonación y la función masticatoria. La reconstrucción inmediata después de la resección es una buena alternativa para evitar una segunda operación, y la planificación virtual prequirúrgica garantiza la eliminación completa de la lesión utilizando guías de corte y cubriendo todo el defecto con una prótesis articular aloplástica personalizada.

PALABRAS CLAVE: osteocondroma, prótesis articular personalizada aloplástica, reemplazo total de la articulación, tumor osteogénico benigno.

\section{REFERENCES}

Burgess, M.; Bowler, M.; Jones, R.; Hase, M. \& Murdoch, B. Improved outcomes after alloplastic TMJ replacement: analysis of a multicenter study from Australia and New Zealand. J. Oral Maxillofac. Surg., 72(7):1251-7, 2014.

Elledge, R.; Attard, A.; Green, J.; Lowe, D.; Rogers, S. N.; Sidebottom, A. J. \& Speculand, B. UK temporomandibular joint replacement database: a report on one-year outcomes. Br. J. Oral Maxillofac. Surg., 55(9):927-31, 2017.

Fletcher, C: Unni, K \& Mertens, F. Chapter 10: Cartilage Tumors. Osteochondroma. In: World Health Organisation Classification Of Tumours: Pathology And Genetics Of Tumours Of Soft Tissue And Bone.Vol. 5. 3rd ed. Lyon, IARC Press, 2002. pp.234-6.

Gerbino, G.; Zavattero, E.; Bosco, G.; Berrone, S. \& Ramieri, G. Temporomandibular joint reconstruction with stock and custom-made devices: Indications and results of a 14-year experience. J. Craniomaxillofac. Surg., 45(10):1710-5, 2017.

Ghom, A. G. Benign Tumor of Jaw. In: Ghom, A. \& Ghom, S. A. Textbook Of Oral Medicine. $2^{\text {nd }}$ ed. New Delhi, Jaypee Brothers Medical Publishers, 2010. pp.308.

Kitsoulis, P.; Galani, V.; Stefanaki, K.; Paraskevas, G.; Karatzias, G.; Agnantis N. J. \& Bai, M. Osteochondromas: review of the clinical, radiological and pathological features. In Vivo, 22(5):633-46, 2008.

Mehra, P.; Arya, V. \& Henry, C. Temporomandibular joint condylar osteochondroma: complete condylectomy and joint replacement versus low condylectomy and joint preservation. J. Oral Maxillofac. Surg., 74(5):91125, 2016.

Mercuri, L. G. Alloplastic temporomandibular joint replacement: rationale for the use of custom devices. Int. J. Oral Maxillofac. Surg., 41(9):1033-40, 2012.

Rodrigues, Y. L: Mathew, M. T.; Mercuri, L. G.; da Silva, J. S. P. Henriques, B. \& Souza, J. C. M. Biomechanical simulation of temporomandibular joint replacement (TMJR) devices: a scoping review of the finite element method Int. J. Oral Maxillofac. Surg., 47(8):1032-42, 2018.

Wolford, L. M.; Dingwerth, D. J.; Talwar, R. M. \& Pitta, M. C. Comparison of 2 temporomandibular joint total joint prosthesis systems. J. Oral Maxillofac. Surg., 61(6):685-90, 2003.

Corresponding author:

Dr. Gonzalo Martinovic

Received: $10-02-2020$

Maxillofacial Surgery Service

Accepted: 09-03-2020

Military Hospital

Av. Alcalde Fernando Castillo Velasco 9100

La Reina - CHILE

Email: drmartinovicg@gmail.com 